\title{
Pattern Generalization by Elementary Students
}

\author{
Rusdiana, Suriaty \\ Universitas Mulawarman \\ Samarinda, Indonesia \\ rusdiyana2008@yahoo.com
}

\author{
Akbar Sutadwidjaja, Edy Bambang Irawan, Sudirman \\ Universitas Negeri Malang \\ Malang, Indonesia
}

\begin{abstract}
This paper presents the strategies used by fifth and sixth grade elementary students when they faced problem on pattern generalization. The samples were 3 elementary school students from grade 5 and 6 . Students were given a problem of pattern and asked to make generalizations on the given pattern. The data were analyzed to describe the strategies used by students in solving the problem of generalizing patterns. The results indicated that the students were able to generalize on a pattern and start using mathematical symbols in solving problem. The results also revealed that the students used effective strategies to solve the problem of generalizing patterns. Although pattern generalization is not a new concept for elementary school students, it is considered important because pattern generalization can help students learn arithmetic thinking to algebraic thinking so that students are able to produce rules that can be used to determine any value of the pattern.
\end{abstract}

Keywords-Pattern Generalization, Algebraic Thinking, Problem Pattern)

\section{INTRODUCTION}

Patterning activities can help students from arithmetic thinking to algebraic generalization and produce rules that can be used to determine any value of the pattern [1]. Researchers have demonstrated that patterning activities can encourage students to construct a variety of generalization [2], [3], [4], [1], [5], [6], [7]. However, sometimes generalizations that students do often turn out to represent a false reasoning [1]. The failure in generalizing of patterns happens because students do not recognize the relationship between the patterns [81. Therefore, recommendations are provided regarding the learning of algebra [9]: begin the learning of algebra early (in part, by building on students' informal knowledge), integrate the learning of algebra with the learning of other subject matter (by extending and applying mathematical knowledge), include several different forms of algebra thinking (by applying mathematical knowledge), build students' naturally occuring linguistic and cognitive powers (encouraging them at the same time to reflect on what they learn and to articulate what they know), encourage active learning (and the construction of relationships) that puts a premium on sense-making and understanding.

The importance of establishing the students' understanding of algebraic ideas through informal knowledge that students brought to school includes the notion of pattern [9]. The kindergarten students aged 5-6 years reveal a unique fact. It was found that these children indicated early algebraic thinking [10]. These children already recognized the number more than 20 and could perform addition and subtraction with it.

Therefore, it is important to learn how students solve the problem of patten generalization. In this study, the research question is 'how do students solve the problem on the given pattern?'

\section{THEORETICAL FRAMEWORK}

The term"pattern" means any regularity which is replicated [11]. The objectives of learning about patterns are as follows. For grades 3 through 5, students are expected to "describe, extend, and make generalizations about geometric and numeric patterns; represent and analyze patterns and functions using words, tables, and graphs [12].

The framework is based on the research conducted [4]. In conducting research by involving students from grade 8 on the problems of the pattern, students' strategies can be divided into two types: based on trial and error and commonality on a given problem. Students' ability to generalize lies in how they pay attention to local commonality and then generalize these similarities in a given term.

Evidence from teaching experiments has shown that elementary-school students are able to identify the rules or patterns and use them to predict the next values of the given pattern [13], [14], articulate the general rule verbally [13] $[15][16]$ and symbolically [13][15][16][17][14]. In Indonesia, for elementary students, generalizing the concept of pattern has begun since first grade i.e by knowing and predicting patterns of simple numbers by using image/concrete objects. The generalization is regarded as an important component of activities and developing a generalized algebra is regarded as one of the important goals in mathematics [20]. Through generalization, the general characteristics of the object can be identified so that objects with special characteristic can be classified together. Generalization means carrying reasoning, or communication to a level where the focus is no longer on the cases or situations itself, but the pattern, procedure, structure, and relations among them [9]. 


\section{METHOD}

The samples were students from grade 5 and 6 (2 from grade 5 and 1 from grade 6) in Fastabiqul Khairat Samarinda Islamic Boarding School. Students were given a problem of pattern and asked to make generalizations on the given pattern.

Qualitative data from student work and in-depth interviews were analyzed to describe the strategies used by students in solving the problem of generalizing patterns.

\section{RESULT}

Given cubes stickers problem:

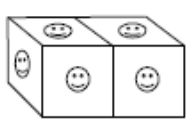

Fig. 1. Cube stickers problem [6]

Students were asked to determine how many stickers were needed if there were 7 cubes, 9 cubes, 49 and $n$ cubes (cubes glued together as in the pictures and one sticker places on each exposed face of each cube. Every exposed face of each cube must have a sticker, so in fig. 1 would need 10 stickers).

\section{Subject 1}

Subject 1 gave the following answer:

$$
\begin{aligned}
& -7 \times 5=35 \\
& -10 \times 5=50 \\
& -49 \times 5=245
\end{aligned}
$$

Jika terdapat a kubus yang digabungkan dan terdapat 10 stiker, $m$ setiap kubus memiliki 5 stiker

Fig. 2. The answer from the first subject

The following is the interview script between the researchers and the student:

Researcher: How do you determine how many stickers are needed for 7 cubes glued together?

Sudent: Here (pointing the problem of cube sticker), there are 2 cube glued together, need 10 stickers, so 1 cube need 5 stickers. If there are 7 cubes you need 7 times 5 sticker"

Researcher: How about 9 cubes?

Students : You need 9 times 5.

Researcher : how about 49 cubes?

Student : 49 times 5.

Researcher: How about $\mathrm{n}$ cubes?

Student : I don't understand.

Researcher: for example, your friend ask you, how many stickers are needed for 5 cubes?

Students : 5 times 5 .
Researcher: I understand, if your friends asked you to determine how many stickers are needed, just multiplied by 5 .

Students : Yes, you just multiplied by 5.

According to [9], the strategy used by subject 1 can be categorized as whole-object strategy, in which students use multiplication in the previous stage to calculate the number of stickers needed. Students do not consider that if cube is glued, the stickers are not counted.

Subject 2

Subject 2 gave the right reason:

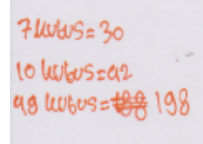

Fig. 3. The answer from second subject

When confirmed:

Researcher: How do you determine how many stickers are needed for 7 cubes that glued together?

Student : The first and the end there were 5 stickers (pointing first cube dan the last cube), and then you count, if there 7 cubes, there are 2 cubes in the fist and the last cube, so you substract by 2 , the rest are 5, multiplied by 4 and then you add $5+5$.

Subject 2 was able to determine the sum of stickers needed for any given cube and able to see that for two cubes that are glued together, the sticker does not count.

Subject 3.

Subject 3 gave explanation for her answer:



Fig. 4. Explanation from subject 3

When confirmed, she could explain her answer:

Researcher: How do you determine how many stickers are needed for 7 cubes that glued together? 
Student : Because the cubes glued together, you not given sticker. So, if there are 7 cubes, there must be two cubes at the edges and there are 5 stickers and the glued sides have 4 stickers.

Researcher: How if there are 100 cubes?

Students : like this, there must two cubes at the edge have 5 stickers, the remaining 98 have 4 stickers.

Subject 3 were able to identified that for cubes that glued together, the sides that glued together does not need stickers.

\section{CONCLUSION}

Students from fifth and sixth grades were able to represent generalization of pattern generalization verbally. These findings concur with those of [21], that elementary school students aged 8 years could think about the relationship between the two groups of data and represent it in a very abstract form. The results also reinforce the research conducted [2] that elementary school students are able to identify the rules or patterns and use them to predict the next values for the given pattern and being able to articulate the general rule verbally.

\section{REFERENCES}

[1] J. R. Becker, \& F. Rivera, Generalizing strategies of beginning high school algebra students. (Online) (www.emis.de $>$ proceedings $>$ PME29), , 2005, accessed 30 April 2016.

[2] D. W. Carraher, A. D. Schliemann, \& B. M. Brizuela, Early Algebra, Early Arithmetic: Treating Operations as Functions, 2003, (Online) (www.citeseerx.ist.psu.edu), diakses 14 Maret 2017.

[3] D. W. Carraher, A. D. Schliemann, B. M. Brizuela, \& D. Earnest, Aritmetic and Algebra in Early mathematics Education, 2006, (Online) (https://pdfs.sematicscholar.org.org), diakses 14 Maret 2017.

[4] D. W. Carraher, A. D. Schliemann, \& B. M. Brizuela, Algebra in Early Mathematics: a Longitudinal Intervention, 2008, (Online) (tsg.icme11.org), diakses 14 Maret 2017..

[5] V. V. Davydov, "Type of generalization in instruction: Logical and psychological problems in the structuring of school curricula," In Kilpatrick, J (Ed.), Soviet Studies in Mathematics Education, Vol. II. Reston, VA: National Council of Teacher of Mathematics, 1972/1990, (Online) (https://www.marxists.org $>$ davydov $>$ ), accessed 30 April 2016.

[6] J. A. Garcia-Cruz, \& A. Martinon, Level of generalization in linear patterns, 1998, (Online) (https://jagcruz.webs.ull.es), accessed 5 Pebruari 2016.

[7] P. Guner, E. Ersoy, \& T. Temiz, $7^{\text {th }}$ and $8^{\text {th }}$ grade students' generalization strategies of patterns, 2013, (Online) (www.iojpe.org >ijge>article>view), accessed 30 Januari 2016.

[8] J. J. Kaput, Teaching and Learning a New Algebra With Understanding, 1999, (Online) (http://www.cimm.ucr.ac.cr), accessed 17 Nopember 2015.

[9] J. K. Lannin, Generalization and justification: the challenge of introducing algebraic reasoning through patterning activities, 2005, (Online) (www.tandfonline.com/doi $>$ pdf), accessed 5 Pebruari 2016.

[10] J. K. Lannin, D. D. Barker, \& B. E. Townsend, Recursive and Explicit Rules: How Can We Build Student Algebraic Understanding?, 2006, DOI:10.1016/j.jmathb.2006.11.004.(Online), (http://www.researchgate.net), accessed 16 Pebruari 2016.

[11] National Council of Teachers of mathematics. Principle and Standard for school mathematics. Reston, VA: NCTM, 2000.

[12] M. M. Papic, J. T. Mulligan, \& M. C. Michelmore, "Assessing the development of preschoolers' mathematical patterning," Journal for
Research in Mathematics education (Vol. 42, No.3), 2011, pp.237-268.

[13] L. Radford, "Students' processes of symbolizing in algebra: A semiotic analysis of the production of signs in generalizing tasks," In T. Nakahara and M. Koyama (Eds.), Proceedings of the 24th Conference of the International Group for the Psychology of Mathematics Education (PME), Vol. IV, Hiroshima, Japan: PME, 2000, pp. 81-88.

[14] L. Radford, Gestures, speech, and the sprouting of signs: a semioticcultural approach to students' types of generalization, 2003, (Online) (http://www.tandfonline.com/loi/html20), diakses 8 Pebruari 2016. DOI. 10.1207/S15327833MTL0501_02.

[15] L. Radford, Algebraic thinking and the generalization of patterns: a semiotic perspective, 2006, (Online) (www.luisradford.ca $>$ pub $>60$ pmena06), accessed 5 Pebruari 2016.

[16] L. Radford, Iconicity and Constraction: A Semiotic investigation of forms of algebraic generalizations of patterns in different context, 2007, (Online) (http://www.reseachgate.net), accessed 30 Januari 2016. DOI. 10.1007.s11858-007-0061-0.

[17] L. Radford, Layers of generality and types of generalization in pattern activites. PNA, 4(2), 2010, pp.37-62.

[18] F. Rivera, Teaching And Learning Patterns In School Mathematics: Psychological And Pedagogical Considerations. New York, NJ: Springer, 2013.

[19] Rusdiana \& Sudirman, Berpikir Secara Aljabar Pada Anak Pra Sekolah, In Kurniawati, R., Pratama, E.Y., \& Sanjaya, A.A. (Eds). Prosiding Seminar nasional Pendidikan MIPA 2015. Bandar Lampung: Jurusan Pendidikan MIPA, FKIP Universitas Lampung, 2015.

[20] A. C. Stephens, I. Isler, T. Marum, M. L. Blanton, E. J. Knuth, \& A. M. Gardiner, 2012. From Recursive Patterns To Corresponcence Rule: Developing Students' Abilities To Engage In Functional Thinking, 2012, (Online) (https://www.researchgate.net), accessed 15 Maret 2017.

[21] E. Warren \& T. Cooper, Generalising the pattern rule for visual growth patterns: Actions that support 8 year olds' thinking DOI10.1007/s10649007-9092-2., 2008 